\title{
Motivasi Dan Strategi Penguatan Petani Kopi Rakyat Dalam Pengolahan Produk Primer Dan Sekunder Di Wilayah Klaster Industri
}

\section{Motivation and Empowerment Strategyes of Smallholders Coffee Farmers in Diversification Postharvest Sector for Primer and Second in Industry Clusters}

\author{
Hesti herminingsih $^{\# 1}$ dan Sudarko ${ }^{* 2}$

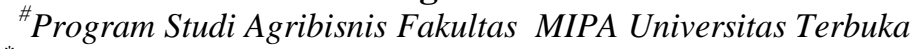 \\ *Program Studi Agribisnis Fakultas Pertanian Universitas Jember \\ ${ }^{1}$ Email: hestih@ecampus.ut.ac.id \\ ${ }^{2}$ Email: darco.faperta@unej.ac.id
}

\begin{abstract}
In Bondowoso Regency,coffee agribusiness development must be full supported with postharvest sectors for primer (green coffee) and second products (roasted bean coffee, ground coffee, instant coffee, etc.). Aims of the research were 1) to analyze variations innovation and technology of farmers postharvest sector for primer and second products, 2) to calculat level motivation of smallholders coffee farmers farmers at postharvest sector for primer products, 3 ) to calculat level motivation of smallholders coffee farmers at postharvest sector for second products 4) to formulate some strategy alternative to development groups of smallholders coffee farmers.

The research has been conducted from August to October 2013. It used descriptif quantitative methods. The research used was a survey using 30 respondents from and 10 informants from all of center smallholders coffee farmers and stakeholders in Industry clusters Area Bondowoso Regency. Data analysis by descriptif, likert scale and Fields Factors analysis (FFA)

The result showed that; 1) variations innovation and technology of farmers postharvest sector for primer and second products is good category. 2) level motivation of smallholders coffee farmers at postharvest sector for primer products were high level, 3 ) level motivation and ability of smallholders coffee farmers at postharvest sector for second products were average level, 4) the strategy alternative to development smallholders coffee farmers with optimalisation and introduction coffee roaster and grider for group farmer scale in agribusiness development perspectives
\end{abstract}

Keywords: Coffee bean, motivation, Empowerment Strategyes, smallholders coffee farmers.

\section{PENDAHULUAN}

Di bidang usaha perkebunan, Kabupaten Bondowoso memiliki potensi besar 5 komoditi yang terdiri dari kelompok tanaman tahunan, tanaman semusim, dan tanaman rempah penyegar, sedangkan dari semua komoditas tersebut yang diprioritaskan adalah komoditas kopi. Kopi menjadi komoditas yang diunggulkan baik secara lokal, regional maupun nasional bahkan konon memiliki citrarasa nomor 3 sedunia (Dishutbun, 2012). Kabupaten Bondowoso juga merupakan salah satu daerah penghasil utama kopi di wilayah Provinsi Jawa Timur. Luas 12.692.84 ha. Seluas 7.332 Ha merupakan kebun kopi jenis Arabika milik PTPN 12 sedangkan seluas 5.363.84 merupakan kebun yang diusahakan oleh rakyat yang terdiri dari kopi Robusta $(83 \%)$ yang ditanam pada ketinggian 600-900 m mdpl dan sisanya adalah kopi Arabika (17\%) yang ditanam pada Ketinggian diatas 1.000. m dpl (Puslitkoka, 2010). Kopi merupakan komoditi perkebunan yang mempunyai peran dan potensi strategis di 
Kabupaten Bondowoso,oleh sebab itu masyarakat Bondowoso patut bangga dan bersyukur karena berdasarkan sejarah perkopian di Indonesia terungkap bahwa java coffee yang cita rasanya sangat dikenal di Pasar Internasional konon berasal dari Bondowoso, hal ini membuktikan bahwa Kopi Arabika asal Bondowoso mendapat pengakuan luas karena mempunyai karakter cita rasa yang spesifik Kopi yang diusahakan oleh petani kopi rakyat pada umumnya dan Kabupaten Bondowoso sebagian besar masih berkualitas rendah. Penyebabnya penguasaan inovasi teknologi sangat minim sehingga berdampak pada harga dan keberlanjutan produksi. Selain itu minimnya peran kelembagaan yang ada menambah deret panjang permasalahan dan ketertinggalan petani kopi rakyat. Upaya peningkatan mutu biji kopi rakyat sudah saatnya diarahkan melalui pendekatan agribisnis. Dengan pola ini, petani tidak lagi dilihat sebagai individu dengan kemampuan di bidang produksi yang terbatas. Konsep agribisnis bertumpu pada pemberdayaan para petani agar memiliki motivasi dan kemampuan yang mumpuni dalam usaha tani kopi baik secara individu maupun secara kelompok.

Sejak tahun 2010 Pemerintah Kabupaten Bondowoso kerjasama dengan Pusat Penelitian Kopi dan Kakao Indonesia, Bank Indonesia, Eksportir dan lembaga terkait lainnya telah membangun Klaster Industri. Pada program tersebut telah dilakukan langkah-langkah percepatan peningkatan mutu kopi dengan pembinaan, pendampingan mulai dari budidaya, pengolahan dan pemasaran untuk peningkatan mutu dan produksi menuju kawasan penghasil kopi specialty. Saat ini klaster kopi rakyat tengah dikembangkan di areal perkebunan seluas 7.526 ha. Petani memperoleh pembiayaan dari Bank Jatim senilai Rp500 juta, sedangkan harga kopi sudah disepakat lewat MoU sebesar Rp38.000 per $\mathrm{kg}$. Nilai jual ditingkat petani iti sudah naik hampir dua kali lipat dari sebelumnya terdapat pengolahan harga jual kopi umumnya hanya sekitar Rp17.000 per $\mathrm{kg}$.

Untuk meningkatkan pendapatan Petani Kopi dan Pendapatan Negara upaya yang ditempuh adalah melalui peningkatan produktivitas dan mutu hasil yang berorientasi pada ekspor, maka telah dijalin kerjasama antara Pemerintah Kabupaten Bondowoso dengan Bank Indonesia, Pusat Penelitian Kopi dan Kakao Indonesia, Bank Jatim, Perum Perhutani, dan PT. Indokom Citra Persada. Melalui dukungan anggaran yang berasal dari APBN Kementerian Pertanian untuk Pembangunan Unit Pengolahan Hasil (UPH) Kopi, maka pada tahap awal telah direalisasi kegiatan pembinaan pengembangan mutu Kopi Arabika. Oleh karena itu, upaya strategis dalam mendukung dan mempercepat pengembangan klaster industri kopi rakyat adalah meningkatkan motivasi adopsi inovasi teknologi diversifikasi pengolahan primer (biji kopi yang bermutu tinggi) dan sekunder (pengolahan menjadi kopi biji sangria, bubuk, bahkan sirup dan produk lain siap konsumsi), sehingga petani kopi rakyat melalui kelembagaan kelompotani dan Unit Pengolahan Hasil tersebut akan mampu menghasilkan produk yang kompetitif dan efisiensi tinggi. Tujuan khusus yang ingin dicapai dalam penelitian ini adalah: (1) Menggambarkan dan mengidentifikasi kondisi perkembangan inovasi teknologi dan kendala utama dalam kepengolahan primer dan sekunder kopi rakyat di Wilayah Klaster Industri Kopi di Kabupaten Bondowoso. (2) Mengetahui tingkat motivasi petani kopi rakyat dalam diversifikasi pengolahan primer di Wilayah Klaster Industri Kopi di Kabupaten Bondowoso. (3) Mengetahui tingkat motivasi petani kopi rakyat dalam diversifikasi pengolahan sekunder di Wilayah Klaster Industri Kopi di Kabupaten Bondowoso.(4) Menyusun dan merumuskan strategi untuk penguatan kelompoktani kopi rakyat dalam pengolahan primer dan sekunder kopi di Wilayah Klaster Industri Kopi di Kabupaten Bondowoso.

\section{METODOLOGI PENELITIAN}

Penelitian ini sudah dilaksanakan pada bulan Agustus sampai Oktober 2013. Daerah penelitian ditentutan secara sengaja (purposive method) yaitu di Wilayah Klaster Industri Kopi di Kabupaten Bondowoso. Dasar pertimbangan pemilihan daerah tersebut dikarenakan (1) di wilayah tersebut berpotensi untuk dikembangkan dalam diversifikasi pengolahan produk primer dan sekunder kopi dengan pendekatan agribisnis; (2) mulai tahun 2010 diwilayah tersebut dibentuk klaster industri kopi yang berbasiskan Unit Pengolahan Hasil (UPH). Metode penelitian yang digunakan adalah metode deskriptif dan analitis (Nazir, 1999). Populasi dalam penelitian ini adalah seluruh petani yang bergabung dalam UPH di Wilayah Klaster Industri Kopi di Kabupaten Bondowoso. Sampel adalah bagian dari populasi dan karakteristik yang dimiliki oleh populasi, dan sampel ditentukan secara simple random (Nazir, 1999) dari setiap UPH secara proporsi diambil sampai sejumlah 30 petani kopi rakyat dengan mempertimbangkan keterambilan jenis kopi yang diusahakan baik kopi Robusta maupun Arabika. Untuk responden FFA diambil 10 sampel dari stakeholder perkopian (unsur pemerintah, Swasta/Eksportir, Ketua Kelompok, Petani dan Akademisi/peneliti). Dalam penelitian ini menggunakan 2 data yaitu: (1) Data primer, (2.) Data Sekunder. (1) Untuk mengetahui kondisi 
Hesti herminingsih, Sudarko. Motivasi Dan Strategi Penguatan Petani Kopi Rakyat Dalam Pengolahan Produk Primer Dan Sekunder Di Wilayah Klaster Industri.

perkembangan inovasi teknologi diversifikasi pengolahan primer dan sekunder kopi di Wilayah Klaster Industri Kopi di Kabupaten Bondowoso digunakan analisis deskriptif berdasarkan data primer, observasi lapangan dan data sekunder yang tersedia. (2) Untuk mengetahui tingkat motivasi dan kemampuan petani kopi dalam penelitian ini menggunakan skala model likert yang ditetapkan melalui pendekatan derivasi normal (Z) dengan tujuan untuk memberi bobot (skor) dari masing-masing jawaban. Skor yang digunakan untuk setiap indikator memiliki nilai terendah 1 dan nilai tertinggi 5. Penentuan skor menggunakan skala likert dengan skoring berdasarkan pengukuran sebagai berikut (Morowati, 2003) : Kriteria pengambilan keputusan : Penjumlahan skor tersebut dikelompokkan menjadi 3 tingkatan, yaitu; tingkat motivas rendah, tingkat motivasi dan sedang dan tingkat motivasi tinggi. (3) Untuk menjawab permasalahan mengenai strategi untuk penguatan kelompotani kopi dalam dalam pengolahan primer dan sekunder kopi di Di Wilayah Klaster Industri Kopi di Kabupaten Bondowoso menggunakan analisis faktor pendorong dan penghambat (FFA) dan divalidasi dengan Fokus Groups Discussion (FGD) dengan pihak-pihak terkait agar upaya yang ada sesuai dengan fakta dan aplikatif di tingkat lapang.

\section{PEMBAHASAN}

1. Kondisi perkembangan Inovasi Teknologi pengolahan primer sekunder kopi dan Kendala Utama di Kabupaten Bondowoso.

Perkembangan kopi di Kabupaten Bondowoso selama 5 (lima) tahun terakhir perkembangan areal yang meningkat, demikian juga untuk produksinya. Hanya produktivitasnya termasuk rendah, karena idealnya produktivitas kopi Robusta adalah mulai $800 \mathrm{~kg} / \mathrm{ha}$ sampai 3.700 $\mathrm{kg} / \mathrm{ha}$ (tergantung klon bahan tanamnya). Selain perkebunan kopi rakyat, juga terdapat perkebunan kopi yang ada di wilayah kerja (hutan) Perhutani yang pada Tahun 2009 luasnya lebih dari setengah luas perkebunan kopi rakyat dan produktivitas yang lebih tinggi. Perkebunan kopi Perhutani ini sebenarnya diusahakan oleh masyarakat, hanya saja status lahannya adalah di bawah pengelolaan Perum Perhutani dan biasanya berupa hutan produksi. Sedangkan untuk kopi arabika perkembangan areal dan produksinya fluktuatif tetapi cenderung meningkat, tetapi produktivitas cenderung menurun. Selain menurun, produktivitasnya juga lebih kecil dari idealnya dan dari jenis kopi robusta. Selain dari perkebunan rakyat, sebagaimana kopi robusta, kopi arabika di Bondowoso juga berasal dari perkebunan Perhutani yang juga diusahakan rakyat.
Produktivitas kopi arabika dari kebun Perhutani juga lebih tinggi dari perkebunan rakyat yaitu sebesar $700 \mathrm{~kg} / \mathrm{ha}$ dan mendekati ideal. Awalnya petani kopi di Kecamatan Sumber Wringin tidak melakukan pengolahan primer dan sekunder, petani disana hanya menjual kopinya ke tengkulak melalui sitem tebasan. Pengolahan kopi primer dan sekunder mulai dilakukan sejak adanya UPH yang dibentuk di Kecamatan Sumber Wringin. Namun awalnya yang melakukan pengolahan primer dan sekunder masih tergolong sedikit karena masih ada 5 UPH yang berdiri dan masih banyak petani belum mengerti tentang pengolahan primer dan sekunder. Oleh karena itu mulai dikembangkan wilayah sumber wringin menjadi klaster kopi karena komoditas unggulan disana adalah kopi. Kopi dianggap komoditas unggulan bahwa stakholder disana beranggapan kopi apabila dilakukan pengolahan primer dan sekunder akan memiliki nilai jual yang tinggi daripada dijual dalam bentuk gelondong serta kopi merupakan kopi yang memiliki daya saing yang tinggi di pasar luar negeri sehingga mulai dikembangkan bahwa kecamatan Sumber Wringin sebagai wilayah kluster industri kopi. Klaster Industri kopi mulai terbentuk pada tahun 2011. Klaster industri kopi dibentuk karena untuk mengembangkan komoditas unggulan di Bondowoso salah satunya adalah kopi sehingga mendapatkan nilai tambah yang tinggi dan meningkatkan mutu kopi serta dapat berdaya saing dengan negara lain. Mulai adanya kalster industri kopi hanya terbentuk $5 \mathrm{UPH}$ atau 5 Kelompok tani. Pada saat itu dari 5 kelompok tani atau 5 UPH inovasi dan teknologi yang dimiliki oleh setiap UPH masih minim dan sebagian masih menggunakan alat yang tradisional dalam melakukan pengolahan primer dan sekunder. Namun pada saat ini sudah berkembang secara pesat inovasi teknologi yang digunakan dalam melakukan pengolahan primer dan sekunder. Mulai dari 5 UPH yang berdiri namun saat ini sudah berkembang menjadi 30 UPH yang dibentuk untuk mendorong terbentuknya klaster industri kopi. Terbentuknya 30 UPH di setiap wialayah di kecamatan sumber Wringin dapat membantu petani dalam melakukan pengolahan primer dan sekunder sehingga dapat mendapatkan nilai tambah yang tinggi dan pendapatan yang tinggi. Dari 30 UPH teknologi yang dimiliki sudah berkembang dengan pesat. Namun teknologi yang dimiliki oleh setiap UPH berebeda-beda teknologinya. Namun adanya inovasi teknologi tersebut sudah menunjang petani dalam melakukan pengolahan primer dan sekunder. Perkembangan inovasi teknologi dalam melakukan pengolahan primer dan sekunder saat ini berkembang secara bertahap. Adanya inovasi tekonologi pada 
pengolahan primer dan sekunder pada saat adanya pembentukan Klaster Industri Kopi

Berdasarkan informasi dari berbagai UPH, bahwa dalam melakukan pengolahan primer dari setiap UPH berbeda sistemnya, walaupun sistemnya setiap UPH berbeda maka setiap UPH tetap melakukan pengolahan primer meurut SOP yang sudah ditetapkan atau dianjurkan oleh disbun dan puslit. Apabila SOP yang sudah ditetapkan tidak diterapkan maka hasil atau mutu dari produk olahan tersebut akan berkurang sehingga akan mempersulit petani dalam proses pemsarannya. Setiap UPH memberikan himbauan kepada anggota petaninya untuk melakukan pengolahan primer karean dengan melakukan pengolahan primer akan mendapatkan nilai tambah yang lebih tinggi daripada dijual dalam bentuk gelondong atau dalam bentuk ose. berdasarkan informasi dari berbagai UPH tersebut tidak semuanya anggotanya mengetahui proses pengolahan kopi primer karena petani tidak mau susah sehingga sebagian petani hanya menjual kopinya dalam bentuk gelondong di setiap UPH masing-masing dan ada juga yang sistemnya menitip. Sistem menitip ini maksudnya petani menitipkan hasil kopinya dalam gelonodong untuk dilakukan pengolahan primer sehingga hasilnya dipasarkan melalui setiap UPH secara bersama-sama. Pada dasarnya sebagian petani disana tidak mau melakukan pengolahan primer karena dianggap bahawa melakukan pengolahan primer memerlukan waktu yang lama dan membutuhkan keahlian yang cukup dan petani beranggapan prosesnya rumit. Oleh karena itu petani sebagian besar sebagai pemasok bahan baku untuk pengolahan primer dan sekunder.

Namun di lapang menunjukkan bahwa dengan 30 UPH teknologi yang dimiliki ternyata berbedabeda dan sebagian pengolahannya masih menggunakan alat tradisional. Inovasi teknologi yang sudah cukup dan dalam kategori lengkap banyak yang dimiliki UPH yang baru terbentuk, namun UPH yang sudah lama terbentuk teknologi yang dimiliki masih dalam kategori minim dan masih menggunakan teknologi yang tradisional. Teknologi yang dimiliki UPH yang lengkap untuk menunjang dalam pengolahan primer dan sekunder adalah pulper, huller, alat pencuci kopi, seller, alat packacing, alat penyangrai kopi, para-para, dan mesin selep. UPH yang baru terbentuk mulai adanya klaster sudah banyak memiliki teknologi yang cukup canggih untu melakukan pengolahan primer dan sekunder sehingga dapat mempercepat proses pengolahannya tersebut. Namun disisi lain ada beberapa UPH yang belum memilki teknologi yang lebih modern, hanya beberapa teknologi yang dimiliki misalnya pulper, huller, mesin selep ,parapara, dan alat selain itu dilakukan secara tradisional. Walaupun adanya keterbatasan teknologi tersebut UPH tetap menerapkan prosesnya pengolahannya berdasarkan SOP yang sudah dianjurkan walaupun masih menggunakan teknologi yang modern. Kendala yang dihadapi oleh dalam melakukan pengolahan primer adalah mengenai teknologi yang masih minim, karena tidak semua UPH memiliki teknologi yang secara keseluruhan membantu dalam proses pengolahan primer sehingga membutuhkan waktu yang lama dalam melakukan pengolahan primer. Disisi lain yang menjadi kendala yaitu kurang pengetahuan petani dalam melakukan pengolahan primer, tidak semua petani bisa melakukan pengolahan primer secara SOP, hanya sebagian yang bisa melakukan pengolahan primer msalnya dari setiap UPH yang mengerti proses pengolahan primer hanya pengurus dari setiap UPH tersebut. Hal itu disebabkan kuranganya keinginginan petani dalam melakukan pengolahan primer karena dianggap melakukan ppengolahan primer cukup rumit dan membutuhkan waktu yang lama apalagi kebutuhan setiap petani berbeda-beda sehingga petani hasil panennya dijual langsung melalui tengkulak atau dijual setiap UPH tersebut.

Kendala yang cukup mengahambat dalam melakukan pengolahan primer adalah mengenai cuaca yang tidak menentu. Cuaca tersebut sangat mempengaruhi proses pengolahan primer karena apabila cuaca tersebut tidak mendukung dalam melakukan pengolahan maka akan berakibat pada kualitas dan mutu yang dihasilkan dar pengolahan primer.

Kendala yang dihadapi pada saat pengolahan sekunder adalah mengenai teknologi yang digunakan juga minim dan masih bersifat tradisional serta kurangnya pengetahuan dalam penggunaan tentang teknologi yang digunakan dalam pengolahan sekunder. Teknologi meruapakan hal yang utama dalam melakukan pengolaha sekunder, selain itu petani juga kurang mengerti mengenai pengolahan sekunder hanya beberapa orang yang mengerti prosesnya sesuai dengan petunjuk dari puslit. Petani juga kurang mengerti dalam menjaga mutu dan kualitas dari masing-masing produk yang dihasilkan. Kendala yang lain adalah mengenai pemasaran. masyarakat luas.

2. Tingkat motivasi petani dalam pengolahan primer kopi di Wilayah Klaster Industri Kabupaten Bondowoso.

Motivasi petani sebelum terbentuknya kluster industri kopi dalam melakukan pengolahan primer masih tergolong rendah karena tidak adanya teknologi yang digunakan dalam melakukan pengolahn primer dan kurang pengetahuannya petani dalam mengolah kopi primer serta kurangnya pengetahuan petani dalam memelihara kebun kopinya. Awalnya sebelum 
Hesti herminingsih, Sudarko. Motivasi Dan Strategi Penguatan Petani Kopi Rakyat Dalam Pengolahan Produk Primer Dan Sekunder Di Wilayah Klaster Industri.

adanya wilayak kluster tersebut petani menanam kopinya masih dalam bentuk lanjuran dan prosesnya panennya masih dalam bentuk rajutan atau dalam kondisi sekali panen dan langsung dijual kepada tengkulak dalam bentuk gelonodong. Namun mulailah adanya penyuluhan dari piak disbun mengenai cara bertanam kopi yang baik dan memelihara kopi yang baik agar dapat meningkatkan produktivitas kopi tersebut maka petani di daearah tersebut mulai menerapkan himbauan dari penyuluh untuk melakukan pemangkasan agar mendapatkan produktivitasnya menjadi tinggi. namun dari himbuan tersebut yang dilakukan oleh penyuluh tidak semua petani menerapkan karena petani beranggapan bahwa melakukan pemeliharaan tersebut membutuhkan banyak biaya sehingga masih banyak yang melakukan penanaman dalam bentuk lajuran.

Namun lama kelamaan pihak disbun untuk merangsang petani agar melakukan perbaikan dalam melakukan pemeliharaan kopinya dengan melakukan pemangkasan maka pihak disbun langsung mempraktekan cara-caranya dilapang agar petani di daerah sana bersedia mengikuti anjuran yang diberikan oleh pihak disbun. Namun lama kelamaan terbukti dengan melakukan pemangkasan tersebut produktivitas kopi menjadi meningkat. Adanya tersebut mulailah berkembangnya produksi kopi di Kabupaten Bondowoso dan stakholder didaerah tersebut dengan pihak-pihak terkait merencanakan membetuk kluster kopi dengan memtuskan berorientasi kepada pangsa pasar terlebih dahulu. Oleh karena itu dengan berorientasi pasar terlebih dahulu maka dapat merangsang petani untuk melakukan proses tanam, pemeliharaan dan pemanenan serta pengolahan sesuai yang dianjurkan dengan pihak-pihak yang terkait.

Adanya kepastian pasar terhadap produk kopi dimulai adanya kemitraan dengan pihak eksportir atau kerjasama dengan pihak indocom. Kemitraan petani yang terjadi dengan pihak eksportir dimulai mulai tahun 2011. Awalnya kemitraan yang dilakukan antara petani kopi di bondowoso dijembatani oleh pihak puslit yang dilakukan secara terbuka antara petani, stakholder yang ada disana, pihak eksportir dan pihak puslit. Kemitraan yang dijalani dapat dikenal dengan nama mutramed yang artinya model kemitraan bermediasi. Oleh karena itu petani menjadi termotivasi melakukan pengolahan primer dan petani mendapatkan harga yang lebih tinggi dengan hasil olahan tersebut dengan menjalankan pola kemitraan dengan pihak eksportir. Namun adanya kemitraan tersebut bahwa mutu dan kualitas yang dihasilkan harus bagus dan prosesnya harus sesuai dengan SOP yang dianjurkan. Apabila tidak menrepkan SOP maka pihak eksportir tidak mau menerima hasil olahan tersebut.

Walaupun sudah ada kepastian pasar maka masih banyak yang tidak bersedia melakukan pengolahan primer karena petani beranggapan bahwa melakukan pengolahan primer rumit dan membutuhkan waktu yang lama apalagi kebutuhan setiap petani berbeda-beda sehingga petani berinisiatif menjual hasil kopinya langsung kepada tengkulak atau di UPH masing-masing. Namun ada petani yang melakukan pengolahan primer dengan menitipkan hasil panennya di UPH masing-masing untuk diproses dalam pengolahan primer sehingga hasil olahannya langsung dijula secara bersama-sama di UP tersebut. Proses pengolahan primer dari setiap UPH sama sistemnya yaitu dilakukan secara bersama-sama di UPH masing-masing sehingga mempermudah petani dalam melakukan pengolahan dan mengetahui cara-cara pengolahan primer yang baik sesuai SOP yang dianjurkan dan di UPH juga tersedia teknologi yang digunakan dalam pengolahan sehingga dapat mempermudah petani dalam melakukan pengolahan dan dapat mempercepat proses pengolahannya tersebut.

3. Tingkat motivasi petani dalam pengolahan sekunder kopi di di Wilayah Klaster Industri Kabupaten Bondowoso

Tingkat motivasi petani kopi rakyat dalam pengolahan sekunder kopi di Wilayah kluster Industri kopi pada saat ini kategori sedang saja. Motivasi petani melakukan pengolahan sekunder dikarenakan nilai keuntungan yang didapat dalam pengolahan sekunder lebih besar dari pada pengolahan kopi secara primer. Namun tidak semua petani melakukan pengolahan sekunder hanya beberapa petani yang melakukan pengolahan sekunder dari $30 \mathrm{UPH}$ terdapat 27 petani yang melakukan pengolahan sekunder. Berdasarkan hasil wawancara dari 27 petani yang melakukan pengolahan sekunder yang sudah terdaftar di departemen kesehatan hanya 4 petani yang termasuk stakholder petani kopi di Kecamatan Sumber Wringin yaitu merek rajawali, nuri, bondowoso coffe dan cap jago dan anggota tersebut aktif dalam UPH tersebut. Awalnya pengolahan sekunder yang melakukan pertama adalah bapak bambang selaku sebagai gapoktan kecamatan sumber wringin dengan memiliki merek cap rajawali. Adanya pengolahan sekunder beroeientasi untuk menciptakan produk hilir dari kopi serta bertujuan untuk meningkatkan pendapatan petani. Awalnya petani tidak memiliki keinginginan atau berminat dalam pengolahan sekunder walaupun sudah ada pelatihan-pelatihan yang dilakukan oleh pemerintah dan puslit untuk 
menjaga mutu dan kualitasnya dari produk kopi bubuk yang dimiliki. Penyerapan teknologi dalam pengolahan kopi sekunder masih kurang sehingga petani belum bisa memahami standart mutu yang diinginkan konsumen. Namun dengan adanya kurang mintanya petani dalam melakukan pengolahan sekunder maka dari pihak pemerintah, dinas perkebunan dan dari pihak puslit yang selalu mendapingi petani kopi di Kecamatan Sumber Wringin selalu memeberi pengertian tentang keuntungan yang didapat dari hasil pengolahan kopi sekunder, serta pihak puslit memberikan pelatihan mengenai kualitas kopi yang baik dalam pengolahan tersebut. Menentukan kualitas yang baik bisa ditentukan dari tingkat kematangan biji kopi yang disangrai dan warna yang dihasilkan dari kopi yang sudah disangrai. Tingkatan warna untuk mengetahui kualitas kopi bubuk dari warna light, medium dan dark. Kisaran suhu untuk menyangrai untuk warna light adalah 1900-1950 , untuk warna medium dengan suhu kisaran 20002050 , sedangkan untuk warna dark dengan suhu diatas 2050. Tingkat kematangan tersebut sesuai keingginan warna dapat diketahui dari aroma, dan jatuhnya kulit ari berdasarkan pengalaman . Selain pelatihan tersebut maka dari pihak puslit untuk menjaga mutu dan kualitas dari kopi bubuk pihak puslit juga melakukan pelatihan mengenai uji cita rasa.

Adanya beberapa pelatihan yang dilakukan akhirnya petani berkeinginan melakukan pengolahan kopi sekunder, yang awalnya hanya sedikit yang melakukan pengolahn kopi sekunder, namun pada saat ini mulai berkembang dan banyak yang melakukan pengolahan sekunder walaupun masih dalam kategori awal petani melakukan pengolahan sekunder. Pengolahan kopi sekunder terdapat SOP yang harus dianjurkan dalam pengolahan sekunder. Petani yang melakukan pengolahan sekunder mengikuti SOP yang dianjurkan dalam pengolahan sekunder. Namun dalam pengolahan sekunder teknologi yang digunakan masih tegolong sederhana dan kapasitas produksinya juga dalam kondisi sedikit. Oleh karena itu petani di Desa Sumbe Wringin dalam meproduksi kopi bubuk dalam skala kecil terlebih dahulu

Pengolahan sekunder disisi lain dapat meningkatkan nilai tambah kopi menjadi kopi bubuk namun disisi lain terdapat kendala yang dihadapi petani kopi dalam melakukan pengolaha sekunder yaitu mengenai pemasaran karena pangsa pasar untuk produk olahan kopi bubuk belum jelas masih dalam lingkungan sekitar dan belum adanya kemintraan dengan pihak luar. Namun ada beberapa yang sudah menembus pangsa di luar daerah denga merek cap rajawali. Pemasaran merek tersebut sudah samapi surabaya, kalimantan, dan daerah lainnya. Strategi Penguatan Kelompoktani/UPH di Wilayah Klaster Industri Kabupaten Bondowoso.

Pada dasarnya motivasi petani di wilayah kluster dengan adanya UPH adalah tinggi karena dengan adanya UPH maka akan mempermudah petani kopi dalam melakukan pengolahan primer dan sekunder. Di dalam UPH terdapat teknologi yang menunjang dalam proses pengolahan kopi primer dan kopi sekunder sehingga memperlancar dalam pengolahan serta standart mutu dan kualitas dapat terjaga sesuai dengan keingginan dari konsumen dan dapat menambah nilai tambah kopi menjadi olahan kopi dengan harga yang tinggi. Selain faktor adanya UPH petani termotivasi melakukan pengolahan kopi adalah adanya kepastian pasar dengan menjalin kemitraan dengan eksportir sehingga petani ingin melakukan pengolahan primer dan dengan adanya kemitraan maka petani mendapatkan harga yang lebih tinggi daripada menjual dengan sistem tebasan kepada tengkulak, namun disisi lain juga didukung dengan bahan baku yang melimpah sehingga petani tidak membuang kesempatan untuk mendapatkan keuntungan yang besar dengan melakukan pengolahan primer dan pengolahan sekunder. Faktor -faktor yang mendorong petani dalam melakukan pengolahan kopi primer dan sekunder tersebut saling berhubungan satu sama lain sehingga petani termotivasi dalam melakukan pengolahan primer dan sekunder.

Berdasarkan faktor-faktor pendorong petani melakukan pengolahan primer dan sekunder yang paling mendorong adalah adanya kemitraan pasar dengan pengepul dan ekspotir. Bahwa dapat diketahui berdasarkan pernyataan stakholder yang ada di Kecamatan Sumber Wringin sebelum adanya terbentuknya UPH maka stakholder awalnya menentukan pasarnya terlebih dahulu karena kepastian pasar sangat penting dalam proses pengembangan kopi di Kecamatan Sumber Wringin sehingga faktor lainnya sebagai pendukung dalam proses pengembangan wilayah kluster industri kopi. Adanya kepastian pasar maka petani menjadi termotivasi untuk melakukan pengolahan primer dan juga menjadi intensif dalam melakukan pemeliharaan atau perawatan kebun kopinya dan mulai melakukan petik merah dan tidak lagi melakukan petik secara rajutan.

Dalam proses startegi penguatan kelembagaan pengolahan kopi primer dan sekunder selain ada faktor pendorong ada juga faktor penghambat. Pada dasarnya petani kopi disana bersifat konsumtif sehingga akan menghambat dalam melakukan pengolahan primer dan sekunder. Karena petani sudah terbiasa dengan melakukan penjualan kopinya denga sistem tebasan sehingga hasil panennya digunakan untuk 
Hesti herminingsih, Sudarko. Motivasi Dan Strategi Penguatan Petani Kopi Rakyat Dalam Pengolahan Produk Primer Dan Sekunder Di Wilayah Klaster Industri.

memenuhi kebutuhan hidupnya daripada produksi hasil kopinya diolah menjadi kopi primer dan sekunder. Oleh karena itu petani terhambat dalam melakukan pengolahan kopi primer dan sekunder karena kekurangan modal untuk melakukan pengolahan kopi tersebut. Proses merubah petani yang konsumtif ke petani yang produktif memerlukan waktu lama dan secara bertahap. Pada dasarnya petani tersebut membutuhkan kebutuhan yang berbeda-beda sehingga petani menjual hasil panennya langsung kepada tengkulak atau ke UPH masing-masing.

Namun pada dasarnya adanya kekurangan modal tidak terlalu menghambat petani dalam melakukan pengolahan kopi primer dan sekunder karena petani di Kecamatan sumber Wringin sering mendapatkan bantuan modal dari perbankan, misalnya bank jatim memebrikan petani modal untuk melakukan pengolahan kopi primer dan sekunder dengan melalui perantara, perantaranya adalah koperasi yang ada di Kecamatan Sumber Wringin. Sistem pemberian modal dengan sistem beli.

Pengaruh cuaca yang tidak menentu dapat mempengaruhi proses pengolahan kopi sekunder dan pengolahan primer karean dapat mengahambat petani dalam melakukan proses kopi primer dalam hal penjemuran, apabila penjemuran terhambat maka proses pengolahan kopi primer menjadi terhambat dan kualitas dan mutunya menjadi turun sehingga mengakibatkan kerugian bagi petani. Pengaruh cuaca juga mempengaruhi dalam proses produksi dan produktivitas tanaman kopi. Cuaca kopi yang tidak menentu dapat menurunkan produksi tanaman kopi per-ha.

Adanya harga kopi yang fluktuatif cukup menghambat dalam pengolahan kopi primer dan sekunder karena dapat mempengaruhi proses pemasaran hasil olahan kopi primer dan sekunder. Harga kopi yang naik turun dapat membingungkan petani dalam proses pemasaran. Pada saat menjalin kotrak namun pada saat itu harga kopi melambung tinggi maka petani akan berbondong-bondong menjual kopinya kepada koperasi. Untuk mengatasi harga yang berfluaktif maka salah satunya alternatif petani menjual hasil kopinya dalam bentuk gelondong ke PTP. Oleh karena itu dengan adanya masalah mengenai harga fluktuatif petani memiliki altenatif sendiri untuk mengatasi masalah mengenai harga.

Berdasarkan hasil dari analisis FFA (Tabel 1) yang mendorong petani melakukan pengolahan primer dan sekunder adalah adanya kepastian pasar atau adanya kemitraan pasar dengan pengepul atau eksportir. adanya kemitraan pasar maka petani menjadi termotivasi dalam melakukan pengolaha primer dan sekunder sehingga dapat meningkatkan nilai tambah petani dan dapat meningkatkan pendapatan petani. Selain adanya kemitraan pasar di dukung dengan harga yang diperoleh dengan melakukan kemitraan menjadi lebih tinggi berdasarkan harganya mengikuti harga pasar dunia. Adanya kemitraan dengan pihak eksportir juga membantu petani dalam memasarkan hasil olahannya. Bahwa diketahui bahwa sebelum dilakukan pembentukan kluster untuk mengembangkan komoditas kopi di Bondowoso berorientasi dengan pasar terlebih dahulu sehingga petani menjadi termotivasi melakukan pengolahan primer dan sekunder. faktor pendorong lain sebagi pendukung dalam melakukan pengolahan primer dan sekunder. adanya peralatan juga mendukung petani dalam melakukan pengolahan primer dan sekunder sehingga dapat mempermudah petani dalam melakukan pengolahan primer dan sekunder. namun sebelum adanya teknologi maka dibentuklah suatu kelompok tani atau UPH yang digunakan sebagai jembatan untuk memperoleh peralatan pengolahan kopi sehingga UPH juga sangat berperan positif dalam mendorong petani dalam melakukan pengolahan primer dan sekunder. adanya UPH petani dapat mendapatkan informasi mengenai cara-cara pengolahan kopi secara primer dan sekunder dan petani dapat menggunakan teknologi yang ada di setiap UPH untu melakukan proses pengolahan primer dan sekunder berdasrakn SOP yang dianjurkan oleh pihak puslit.

TABEL 1.

Tabel Evaluasi Faktor Pendorong Petani KoPI RaKyat Dalam MELAKUKan PENGOLAHan KoPI

PRIMER DAN KoPI SEKUNDER DI WILAYAH KLASTER INDUSTRI

\begin{tabular}{|c|c|c|c|c|c|c|c|c|}
\hline No & Faktor Pendorong & $\mathrm{BF}$ & ND & NRK & NBD & NBK & $\begin{array}{l}\mathrm{TN} \\
\mathrm{B} \\
\end{array}$ & $\begin{array}{l}\mathrm{FK} \\
\mathrm{K} \\
\end{array}$ \\
\hline D1 & $\begin{array}{l}\text { Motivasi petani } \\
\text { tinggi }\end{array}$ & 0.16 & 3.00 & 3.52 & 0.48 & 0.57 & 1.05 & 5 \\
\hline D2 & $\begin{array}{l}\text { Peralatan } \\
\text { pengolahan kopi } \\
\text { secara kelompok } \\
\text { sudah ada }\end{array}$ & 0.16 & 4.00 & 3.27 & 0.65 & 0.53 & 1.18 & 4 \\
\hline D3 & $\begin{array}{l}\text { Harga hasil olahan } \\
\text { kopi tinggi }\end{array}$ & 0.16 & 4.00 & 3.82 & 0.64 & 0.61 & 1.26 & 2 \\
\hline D4 & $\begin{array}{l}\text { Adanya kemitraan } \\
\text { pasar dengan } \\
\text { pengepul dan } \\
\text { eksportir }\end{array}$ & 0.19 & 4.00 & 3.75 & 0.75 & 0.70 & 1.45 & $1^{*}$ \\
\hline D5 & $\begin{array}{l}\text { Bahan baku } \\
\text { melimpah }\end{array}$ & 0.16 & 3.00 & 3.45 & 0.49 & 0.56 & 1.05 & 6 \\
\hline \multirow[t]{2}{*}{ D6 } & $\begin{array}{l}\text { Keikutsertaan } \\
\text { dalam kelompok } \\
\text { petani }\end{array}$ & 0.17 & 4.00 & 3.14 & 0.67 & 0.53 & 1.20 & 3 \\
\hline & Jumlah & & & & & & 7.18 & \\
\hline
\end{tabular}

Sumber: Data Primer diolah 2013.

Keterangan:

BF : Bobot Faktor

TNB

: Total Nilai Bobot

ND : Nilai Dukungan

: Faktor Kunci Keberhasilan

NRK : Nilai Rata-rata Keterkaitan

NBD : Nilai Bobot Dukungan

*) Merupakan Faktor Paling Kunci Keberhasilan 
Hesti herminingsih, Sudarko. Motivasi Dan Strategi Penguatan Petani Kopi Rakyat Dalam Pengolahan Produk Primer Dan Sekunder Di Wilayah Klaster Industri.

Berdasarkan hasil dari analisis FFA (Tabel 2) bahwa faktor yang menghambat dalam melakukan pengolahan primer dan sekunder adalah budaya petani yang konsumtif diamana bahwa diketahui setiap petani memerlukan kebutuahan yang berbeda-beda, bahkan apabila ada kebutuhan yang mendesak maka petani langsung menjual hasil panennya dalam bentuk gelondong kepada tengkulak atau di jual di UPH masing-masing dengan alasan ada kebutuhan yang mendesak yang membuat petani tidak melakukan pengolahan primer dan sekunder. selain itu dikarena faktor malas, tidak semua petani melakukan pengolahan primer dan sekunder karena petani beranggapan bahwa melakukan pengolahan primer dan sekunder merasa rumit dan membutuhkan waktu yang lama serta pengetahuan petani juga rendah. Disamping itu petani tidak ingin belajar untuk melakukan pengolahan primer maupun sekunder masih banyak petani yang belum mengetahui cara-cara dalam melakukan pengolahan kopi secara primer dan sekunder karena kuranganya pengusaaan terhadap teknologi yang di setiap UPH dan tidak mengetahui SOP yang harus dijalankan dalam melakukan pengolahan primer maupun sekunder sehingga keadaan tersebut dapat menghambat proses pengolahan kopi secara primer dan sekunder.

$$
\text { TABEL } 2 .
$$

Tabel Evaluasi Faktor Penghambat Petani Kopi

RaKyat Dalam MelakuKan PEngolahan KoPI

PRIMER DAN KoPI SEKUNDER DI WILAYAH KLASTER INDUSTRI

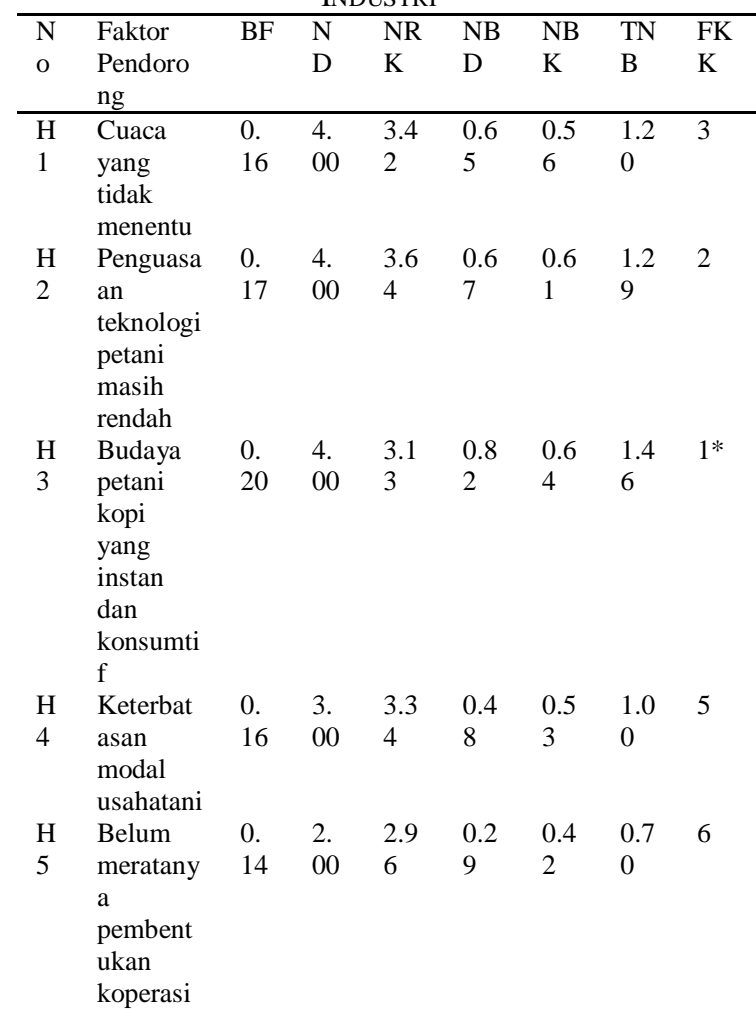

\begin{tabular}{lllllllll}
$\mathrm{H}$ & Harga & 0. & 3. & 3.6 & 0.4 & 0.5 & 1.0 & 4 \\
6 & kopi & 16 & 00 & 0 & 9 & 9 & 8 & \\
& yang & & & & & & & \\
\multicolumn{1}{l}{ flutuaktif } \\
\hline \multicolumn{3}{l}{ Jumlah } & & & & & \multicolumn{3}{c}{$\begin{array}{c}6.7 \\
4\end{array}$} \\
\hline
\end{tabular}

Sumber: Data Primer diolah 2013.

Keterangan:

BF : Bobot Faktor

TNB

: Total Nilai Bobot

ND : Nilai Dukungan

FKK

: Faktor Kunci Keberhasilan

NRK : Nilai Rata-rata Keterkaitan

NBD : Nilai Bobot Dukungan

*) Merupakan Faktor Paling Kunci Keberhasilan

Berdasarkan evaluasi hasil perhitungan

faktor pendorong dan faktor penghambat, diperoleh masing-masing satu pendorong kunci dan penghambat kunci. Skema strategi fokus pengembangan petani kopi dalam melakukan pengolahan kopi primer dan kopi sekunder dapat didijelaskan pada Gambar 1. Berdasarkan Gambar 1 tersebut strategi fokus yang diperoleh berdasarkan FKK pendorong dan FKK penghambat yang telah dipilih dengan cara membentuk lembaga keuangan pada kelompok tani yang dapat membantu petani dengan memberikan pinjaman yang tidak memberatkan petani saat melakukan pinjaman. Selain itu memberikan pelatihan pembentukan usaha mandiri bagi kelompok, serta memberikan pelatihan, pembinaan, dan pendampingan tentang pengolahan primer dan sekunder kopi yang dilakukan petani. Pihak-pihak yang terkait yang dapat membantu adalah Dinas Perkebunan dan Kehutanan Kabupaten Jember, Puslit KOKA, Universitas Negeri maupun Swasta dan Bank dan Koperasi sebagai lembaga keuangan serta pihak swasta atau perusahaan eksportir yang mampu menjembatani dalam kemitraan usaha yang saling sinergis bersama-sama memajukan perkopian di wilayah Klaster Industri Kabupaten Bondowoso. Keragaan medan kekuatan petani untuk pengembangan Petani Kopi dalam melakukan Pengolahan Kopi Primer dan Kopi Sekunder di Wilayah Klaster Industri Kabupaten Bondowoso Jawa Timur dapat dilihat pada Gambar 1 .

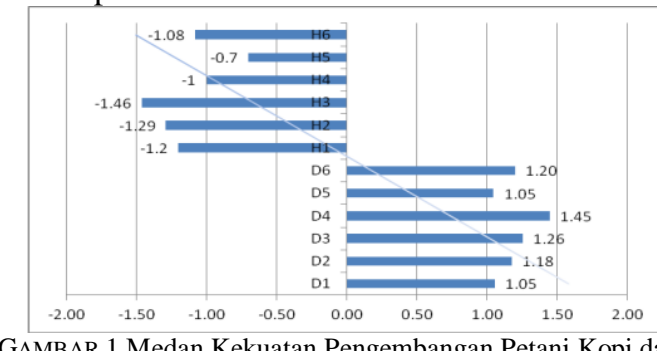

GAMBAR 1 Medan Kekuatan Pengembangan Petani Kopi dalam Melakukan Pengolahan Kopi Primer dan Kopi Sekunder di Wilayah Klaster Industri 


\begin{tabular}{|c|c|c|c|}
\hline \multicolumn{4}{|c|}{ Keterangan: } \\
\hline No & Faktor Pendorong & No & Faktor \\
\hline & & & Penghambat \\
\hline D1 & $\begin{array}{l}\text { Motivasi petani } \\
\text { tinggi }\end{array}$ & H1 & $\begin{array}{l}\text { Cuaca yang tidak } \\
\text { menentu }\end{array}$ \\
\hline D2 & $\begin{array}{l}\text { Peralatan } \\
\text { pengolahan kopi } \\
\text { secara kelompok } \\
\text { sudah ada }\end{array}$ & $\mathrm{H} 2$ & $\begin{array}{l}\text { Penguasaan } \\
\text { teknologi petani } \\
\text { masih rendah }\end{array}$ \\
\hline D3 & $\begin{array}{l}\text { Harga hasil olahan } \\
\text { kopi tinggi }\end{array}$ & $\mathrm{H} 3$ & $\begin{array}{l}\text { Budaya petani } \\
\text { kopi yang instan } \\
\text { dan konsumtif }\end{array}$ \\
\hline D4 & $\begin{array}{l}\text { Adanya kemitraan } \\
\text { pasar dengan } \\
\text { pengepul dan } \\
\text { eksportir }\end{array}$ & $\mathrm{H} 4$ & $\begin{array}{l}\text { Keterbatasan } \\
\text { modal usahatani }\end{array}$ \\
\hline D5 & $\begin{array}{l}\text { Bahan baku } \\
\text { melimpah }\end{array}$ & H5 & $\begin{array}{l}\text { Belum meratanya } \\
\text { pembentukan } \\
\text { koperasi }\end{array}$ \\
\hline D6 & $\begin{array}{l}\text { Keikutsertaan dalam } \\
\text { kelompok petani }\end{array}$ & H6 & $\begin{array}{l}\text { Harga kopi yang } \\
\text { flutuaktif }\end{array}$ \\
\hline
\end{tabular}

Pembentukan lembaga keuangan dapat meminimalkan faktor penghambat, bank sebagai lembaga keuangan diharapkan membantu dalam pembentukan koperasi, koperasi yang ada dan dikelola kelompok diharapkan dapat membantu petani dalam melakukan pinjaman untuk modal melakukan usahatani dengan syarat-syarat jaminan yang harus dipenuhi dan tidak memberatkan petani. Koperasi yang dibentuk harus merupakan kelembagaan yang kuat, memiliki kekuatan secara hukum, memiliki legalitas, dan diakui oleh pemerintah. Saat ini pembentukan koperasi masih tidak merata dikarenakan kurangnya pembinaan dan pendampingan yang menyebabkan koperasikoperasi yang dibentuk tidak dapat bertahan lama.

Terbentuknya koperasi juga diharapkan dapat memenuhi segala kebutuhan sarana produksi petani kopi. Serta budaya petani yang konsumtif yaitu petani lebih menggunakan keuntungan usahataninya untuk memenuhi kebutuhan seharihari dan kebutuhan untuk hiburan dari pada menggunakannya untuk biaya usahatani kopi selanjutnya, sehingga nantinya dengan adanya pembentukan koperasi sebagai lembaga keuangan yang dapat membantu hal tersebut. Keikutsertaan petani dalam kelompok tani yang juga menjadi faktor pendorong akan mendukung berjalanya pembentukan lembaga keuangan berbasis koperasi yang dikelola petani secara kelompok.

Diadakannya pelatihan, pembinaan, dan pendampingan kepada petani oleh Dinas Perkebunan, dan Pusat Penelitian Kopi Kakao Indonesia serta pihak Eksportir secara continually diharapkan dapat membantu mengembangkan usahatani kopi. Saat ini yang menjadi penghambatnya adalah penguasaan teknologi petani yang rendah sehingga dengan adanya kegiatan tersebut petani dapat menjaga dan menggunakan alat pengolahan sesuai kebutuhan kelompok. Pelatihan yang dibutuhkan yaitu untuk melakukan diversifikasi kopi secara primer, pengolahan kopi secara basah. Serta pembinaan dan pendampingan dilakukan sampai petani benarbenar mampu merubah budaya petani yang masih memilih menjual hasil usahataninya dalam bentuk gelondong.

Peralatan yang telah diberikan berupa alat olah basah dan olah kopi menjadi bubuk nantinya akan dapat membantu petani dalam menghasilkan kopi yang bermutu ekspor, sehingga kopi yang dijual mendapatkan harga tinggi dan dapat meningkatkan kesejahteraan petani kopi. Akhirakhir ini anomali cuaca yang terjadi menyebabkan merosotnya produksi kopi. Diadakanya kegiatankegiatan tersebut diharapkan mampu memberikan solusi yaitu dengan menyiasati tanaman naungan sehingga ketika musim hujan maka daun-daun yang ada di tanaman naungan tidak dipangkas agar bunga kopi tidak rontok. Pada saat musim kemarau daun-daun yang ada pada tanaman naungan dipangkas agar sinar matahari dapat masuk dan membantu fotosintesis.

Kegiatan lain dari Dinas Perkebunan, dan Pusat Penelitian Kopi Kakao Indonesia yang dibutuhkan petani adalah pelatihan, pembinaan, pembentukan dan pendampingan usaha mandiri. Pembentukan usaha mandiri melalui pengolahan kopi sekunder (bubuk) dapat dibimbing juga oleh beberapa stakeholder terkait. Mengolah kopi menjadi kopi bubuk akan meminimalkan faktor penghambat yang ada, yaitu harga kopi yang fluktuatif. Ketika harga kopi rendah maka petani melakukan pengolahan kopi sekunder karena harga kopi yang diolah secara sekunder harganya akan stabil dan harga kopi olahan cenderung tinggi. Maka hal tersebut menjadi pendorong petani melakukan pengolahan kopi sekunder. Kegiatan yang dilakukan dari dinas-dinas terkait selaku stakeholders tidak menutup kemungkinan akan menjadikan Klaster Industri Kopi Bondowoso sebagai sentra penghasil kopi berkualitas ekspor serta dapat meningkatkan potensi kopi bubuk lokal.

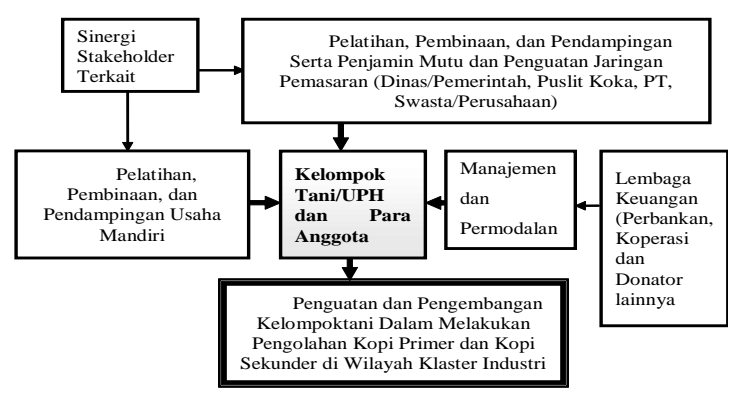


Hesti herminingsih, Sudarko. Motivasi Dan Strategi Penguatan Petani Kopi Rakyat Dalam Pengolahan Produk Primer Dan Sekunder Di Wilayah Klaster Industri.

GAMBAR 2.

Skema Strategi Penguatan dan Pengembangan KELOMPOKTANI KOPI RAKYAT DALAM MELAKUKAN PENGOLAHAN PRIMER DAN SEKUNDER Di WILAYAH KLASTER INDUSTRI KABUPATEN BONDOWOSO.

Semua kegiatan petani kopi secara umum dapat terealisasi dengan baik, dikarenakan adanya faktor pendorong yaitu motivasi petani yang tinggi dalam melakukan pengolahan kopi. Hasil kopi yang melimpah sehingga dapat menjadi bahan baku pengolahan kopi menjadi faktor pendorong selanjutnya, karena kecenderungan petani untuk lebih menjual kopi dalam bentuk gelondong masih belum bisa hilang dan sudah merupakan budaya. Maka dengan adanya hal tersebut stakeholders dari dinas-dinas terkait membantu petani dalam hal memasarkan hasil kopinya kepada eksportir. Hal yang dilakukan adalah memberikan bantuan UPH guna biji kopi yang dihasilkan petani dengan olah basah dapat laku di pasar dunia. Selain itu stakeholders tersebut menjadi penguji mutu biji kopi dan kriteria, sehingga biji kopi tersebut sesuai kriteria untuk diekspor ke negara-negara yang berbeda, karena tiap negara mempunyai kriteria biji kopi ekspor yang diminta.

\section{KESIMPULAN}

Kondisi perkembangan inovasi teknologi pengolahan primer dan sekunder sudah relative maju dan sedang berkembang baik. Adapun kendala utama dalam pengolahan primer dan sekunder kopi di Wilayah Klaster Industri Kopi di Kabupaten Bondowoso adalah belum adanya jaminan pasar yang pasti dan belum tersedianya teknologi kapasitas tinggi untuk skala industry besar. Tingkat motivasi petani kopi rakyat dalam pengolahan primer kopi di Wilayah Klaster Industri Kopi di Kabupaten Bondowoso adalah tinggi. Tingkat motivasi petani kopi rakyat dalam pengolahan sekunder kopi di Wilayah Klaster Industri Kopi di Kabupaten Bondowoso adalah masih sedang. Strategi penguatan kelompoktani kopi rakyat dalam dalam pengolahan primer dan sekunder adalah penguatan sinergitas stakeholder dan lembaga keuangan seperti koperasi yang mampu menyatukan seluruh kekuatan kelompoktani/UPH kopi rakyat di Wilayah Klaster Industri Kopi di Kabupaten Bondowoso.

\section{DAFTAR PUSTAKA}

[1] Cartwright, D dan A. Zander. 1968. Group Dynamics: Research and Theory. Harper \& Row Publishers. New York

[2] [Dishutbun] Dinas Kehutanan dan Perkebunan. 2009. Potensi Perkebunan di Di Wilayah Klaster Industri Kopi di Kabupaten Bondowoso. Jember: Dishutbun.

[3] [Dishutbun] Dinas Kehutanan dan Perkebunan. 2012. Identifikasi Kebutuhan Pengembangan Sumberdaya
Tanaman Kopi Arabika di Kabupaten Bondowoso. Jember: Dishutbun.

[4] Direktorat Jenderal Industri Agro dan Kimia Departemen Perindustrian Jakarta. 2009. Roadmap Industri Pengolahan Kopi. Jakarta.

[5] Direktorat Jenderal Industri Agro dan Kimia Departemen Perindustrian Jakarta. 2009. Roadmap Industri Pengolahan Tembakau. Jakarta.

[6] Pusat Penelitian Kopi dan Kakao Indonesia. 2010. Kajian Pembentukan Klaster Industri Kopi di Kabupaten Bondowoso. Jember: Tidak Publikasi

[7] Morowati, N. 2003. Pengaruh Faktor Sosial dan Tingkat Adopsi Teknologi Usahatani serta Produktivitas terhadap Pendapatan Petani Kedelai. Skripsi, Jember Fakultas Pertanian Universitas Jember.

[8] Nazir, M. 1999. Metode Penelitia. Jakarta:.Ghalia Indonesia.

[9] Sudarko. 2010. "Hubungan Peran Kelompoktani dengan Kemampuan Anggota dalam Usahatani Kopi Rakyat" [tesis]. Bogor: Sekolah Pascasarjana, Institut Pertanian Bogor.

[10] Yusnadi. 1992. "Adopsi Petani Kopi dalam Pengembangan Perkebunan Kopi Rakyat" [tesis]. Bogor: Sekolah Pascasarjana, Institut Pertanian Bogor. 